\title{
EFFECT OF REMOVAL OF LARGE PARTICLES FROM MILLED BARLEY ON GROWTH PERFORMANCE IN BROILER DURING GROWING STAGE
}

(Received: 9. 4. 2014)

\author{
By \\ H. Y. Al-Omari, M. S. Al-Rawashdeh, G.J. Al-Rabadi, \\ M. H. Aludatt" and K.I. Ereifej* \\ Department of Animal Production, Faculty of Agriculture, Mu'tah University, Karak, Jordan \\ *Department of Nutrition and Food Technology, Faculty of Agriculture, Jordan University of Science \\ and Technology, Irbid, Jordan
}

\begin{abstract}
This investigation was conducted to study the influence of separating and regrinding the large particle size of barley as compared to the barley ground coarse feds on improving overall broiler performance and possible change associated with morphology in the digestive system. Thirty chicken were used in the experiment. They were brooded for 21 days and thereafter divided into two groups of treatment. The two diet treatments were coded for particle size, ground barley diet GBD (control), and reground coarse-fraction barley diet (RBD). Each treatment was applied on 15 birds. The experimental period was 21 days (from day 21 to 42 day old). The performance of the broilers was monitored on daily basis. At the end of week six, all birds in each treatment were slaughtered via neck slit, defeathered and eviscerated for carcass and intestinal moropholgy analysis (i.e., relative length of digestive). The results showed that RBD reduced feed intake and improved feed conversion ratio and changed gastrointestinal morphology of broilers during the growing stage. From the processing prospective, regrinding coarse fraction reduced average particle size without producing excess of fines. Regrinding coarse particles of barley could be also an approach to reduce production cost of broiler feed through minimizing feed intake without producing excess of fines.
\end{abstract}

Key words: barley, broiler, digestive system, feed intake, particle size.

\section{INTRODUCTION}

Grain grinding is the first step in feed processing where particle size is reduced to facilitate further steps such as mixing of other feed ingredients (Koch, 1996), increase surface area of grain particles to increase digestibility (Al-Rabadi et al., 2009). For example, for each $100 \mathrm{~mm}$ increase in particle size in ground maize grains, the degree of starch access by alphaamylase was found to decrease by $26.8 \mathrm{~g} / \mathrm{kg}$ starch (Blasel et al., 2006). Reduction of particle size of corn from 900 to $300 \mu \mathrm{m}$ can increase the surface area more than double (Healy et al., 1994). However, fine milling has been reported to cause logistical problems such as feed handling difficulties, capacity reduction of the mill and increased energy consumption during milling (Goodband et al., 1995; AlRabadi 2013). This work describes an experiment which separated the large particles in barley and then reground it to reduce their size, to investigate whether this procedure will improve broiler performance and possible changes associated to morphology in the digestive system. This is a novel alternative to grind large particles and turn them into a smaller size in the first place. The proposed methodology was designed to achieve the benefit of removing large particles without the drawback of generating excessive amounts of dust and fine particles.

\section{MATERIALS AND METHODS} 2.1. Barley grinding and sieving analysis Barley grains were hammer milled (Model No. M.K. 11R180, Kteingesellschaft, Germany) by using $4 \mathrm{~mm}$ screen size. Ground barley (around $100 \mathrm{~kg}$ ) was collected at steady state during milling (constant motor load indicated by constant ammeter reading). Approximately, half the quantity of ground barley was sieved manually used a rectangular $2 \mathrm{~mm}$ sieve $(50 \mathrm{~cm}$ 
x $60 \mathrm{~cm})$ to separate fine particles (approximately 45\%) and coarse fractions (approximately 55\%). The ground-coarse fractions of barley grains were stored in separate containers and then re-milled using the hammer mill fitted with a $4 \mathrm{~mm}$ screen size and then mixed with fine fractions.

To evaluate the processes of grinding, sieving and regrinding, $100 \mathrm{~g}$ sample from each treatment were sieving using a sieve shaker for 15 min. according to ASAE (2003). The particle size distribution of the ground-coarse and the coarse fraction after re-milling and mixing with the fine fraction were determined by size segregation using vertical multiple sieving under gravity with mechanical agitation using a sieve shaker (Model No. SV001, Impact Test Equipment Ltd, UK). Eight screen sieve (Impact Test Equipment Ltd, UK) sizes were selected to give a broad spectrum of particle size ranging from $2.8 \mathrm{~mm}$ to $0.045 \mathrm{~mm}$ (pan), Moreover diameter geometric mean $\left(\mathrm{d}_{\mathrm{gw}}\right)$ and geometric standard deviation $\left(\mathrm{S}_{\mathrm{gw}}\right)$ and particle size distribution (fraction yield percentage) were estimated (Table 1).

In this paper, the term particle size refers to particles that were retained on a particular sieve. Thus, a particle size of $0.5 \mathrm{~mm}$ means that the particles in that fraction passed through the 1.0 $\mathrm{mm}$ sieve, and were retained on the $0.5 \mathrm{~mm}$ sieve. A particle size of $<0.125 \mathrm{~mm}$ means the material passed through the $0.125 \mathrm{~mm}$ sieve and was collected on the pan. The diet treatments were coded for particle size: ground barley diet (GBD) (control) and reground coarse-fraction barley diet (RBD).

\subsection{Birds and diets formulation}

Thirty Hubbard broilers were raised from 21 to 42 day old according to general commercial husbandry. They were raised in floor cages and equipped with a trough drinker and feeder. Feed and water were given $a d$ lib and broilers had a continuous light. Barley (with different level of particle size) based diets were formulated to be iso-caloric and iso-nitrogenous by mixing with other feed ingredients as shown in (Table 2).

\subsection{Data measurements}

At the end of the experimental period (day 42), all broilers in each experimental treatment (15 birds) were weighed for carcass and digestive system evaluation. The birds were slaughtered by cutting the jugular veins, scalded in hot water for about a minute, and the feathers were removed by defeathering machine. The birds were eviscerated and weighed to obtain their dressed carcass weights. The heart, gizzard, liver, spleen, abdominal fat, small intestine, and large intestine were removed and weighed using

Table (1): Means of particle size distribution, geometric mean $\left(d_{\mathrm{gw}}\right)$ and geometric stranded deviation $\left(S_{\mathrm{gw}_{\mathrm{w}}}\right)$ of particle size of milled barley grains at different hammer mill screen size (values are represented as means \pm SE).

\begin{tabular}{|c|c|c|}
\hline \multirow[b]{3}{*}{ Sieve size $(\mathbf{m m})$} & \multicolumn{2}{|c|}{ Barley particle size } \\
\hline & Control & $\begin{array}{l}\text { Reground coarse } \\
\text { fraction }\end{array}$ \\
\hline & Fraction yield $(\%) \pm \mathrm{SE}$ & Fraction yield $(\%) \pm \mathrm{SE}$ \\
\hline 4 & $\mathbf{0} \pm \mathbf{0 . 0 0}$ & $0 \pm 0.00$ \\
\hline 2.8 & $24.3 \pm 0.77$ & $6.6 \pm 0.66$ \\
\hline 2 & $29.6 \pm 0.61$ & $19.9 \pm 0.21$ \\
\hline 1 & $31.7 \pm 0.4$ & $47.0 \pm .04$ \\
\hline 0.5 & $9.2 \pm 0.82$ & $15.4 \pm 0.18$ \\
\hline 0.25 & $3.9 \pm 0.04$ & $7.2 \pm 0.37$ \\
\hline 0.125 & $1.2 \pm 0.02$ & $3.8 \pm 0.45$ \\
\hline 0.045 & $0.1 \pm 0.00$ & $0.1 \pm 0.00$ \\
\hline \multicolumn{3}{|c|}{ Particle size parameters } \\
\hline$d_{g w}(\mathbf{m m})$ & 1.72 & 1.25 \\
\hline $\mathrm{S}_{\mathrm{gw}}(\mathbf{m m})$ & 1.89 & 1.97 \\
\hline
\end{tabular}


Table (2): Ingredients (\%) and calculated analysis (\%) of the experimental diet.

\begin{tabular}{|c|c|}
\hline Ingredient & $\%$ \\
\hline Barley & 45.0 \\
\hline Corn & 13.8048 \\
\hline Soybean meal $(44 \% \mathrm{CP})$ & 26.3752 \\
\hline Soybean oil & 6 \\
\hline a'DCP (Dicalcium phosphate) & 2.5987 \\
\hline Salt $(\mathrm{NaCl})$ & 0.1607 \\
\hline${ }^{b}$ Vit.+Min premix & 0.2 \\
\hline${ }^{c}$ Myco Curb ${ }^{\circledR}$ & 0.1 \\
\hline${ }^{\mathrm{d}}$ Brocon Concentrate ${ }^{\circledR}(35 \%$ CP) & 4.9605 \\
\hline Methionine & 0.3 \\
\hline Lysine & 0.3 \\
\hline Enzyme & 0.05 \\
\hline Calcium carbonate & 0.1 \\
\hline \multicolumn{2}{|l|}{${ }^{\mathrm{e}}$ Calculated analysis } \\
\hline AMEn (kcal/kg) & 2900 \\
\hline Crude protein & 20.0 \\
\hline Crude fibre & 4.86 \\
\hline Methionine & 0.65 \\
\hline Lysine & 1.35 \\
\hline Meth + Cys & 0.88 \\
\hline Calcium & 0.9 \\
\hline Non-phytat phosphorous & 0.78 \\
\hline Sodium & 0.15 \\
\hline Chloride & 0.184 \\
\hline
\end{tabular}

${ }^{\text {a }}$ Dicalcium phosphate Contained $21 \%$ calcium and $20 \%$ phosphorous.

${ }^{\mathrm{b}}$ Vitamin premix provided per kilogram of premix including : Vitamin A,700,000 IU; vitamin D3, 150,000 IU; vitamin E, 75mg; vitamin B1, $100 \mathrm{mg}$; vitamin $\mathrm{K}, 175 \mathrm{mg}$; vitamin B5, $600 \mathrm{mg}$; manganese oxide, $4000 \mathrm{mg}$, ferrous sulphate, $9000 \mathrm{mg}$, zinc oxide, $6000 \mathrm{mg}$, magnisum oxide, $2500 \mathrm{mg}$, potassium iodide, $70 \mathrm{mg}$, sodium selenite, $125 \mathrm{mg}$, copper sulphate, $100 \mathrm{mg}$, cobalt sulphate, $50 \mathrm{mg}$, dicalcium phosphate, $7000 \mathrm{~m}$, sodium chloride, $10000 \mathrm{mg}$.

${ }^{c}$ Mold inhibitor for animal feed (Kemin Industries, U.S.A)

${ }^{\mathrm{d}}$ Brocon Concentrate ${ }^{\circledR}$ (Wafa, B. V., Alblasserdam, Holland)

${ }^{\mathrm{e}}$ Calculated based on analyzed values of feed ingredients (feed composition tables) from

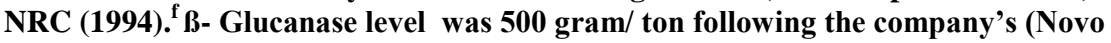

Nordisk, Denamark) recommended level.

a sensitive electronic scale. The dressed carcass and digestive system organ weights were expressed as percentages of the live weights. In addition, the length of the digestive system parts was measured using a tailor's tape. From each bird, $\mathrm{pH}$ measurements were obtained directly from the digesta contents in the lumen of gizzard and proventriculus using a digital $\mathrm{pH}$ meter (Model PL-600, EZDO, Taiwan).

\section{4. Experimental design}

Statistical analysis was carried out using Statistic Software, Version 9.0 (SAS Institute, Cary, NC). The Student $t$ test at 5\% level of significance was used to compare the measured means between the two treatments ( 15 broilers for each treatment. All data were presented as means ( \pm Standard error (SE).

\section{RESULTS}

The effect of hammer mill screen size on the average particle size $\left(\mathrm{d}_{\mathrm{gw}}\right)$, geometric standard deviation $\left(\mathrm{S}_{\mathrm{gw}}\right)$ and the fraction yield on each sieve after sieving for GBD and RBD diets are shown in Table (1). As expected, regrinding coarse fraction of milled barley reduced $\mathrm{d}_{\mathrm{gw}}$ by $0.5 \mathrm{~mm}$. The influence of regrinding coarse fraction of barley grains on $\mathrm{d}_{\mathrm{gw}}$ is attributed to reducing fraction yield of coarse fractions after being milled again Table (1). In this study, regarding coarse fraction reduced the percentage 
of coarse fractions retained on sieves $4 \mathrm{~mm}$ and $2.8 \mathrm{~mm}$ from 54 to $27 \%$.

Influence of barley particle size on broiler performance over the growing period (week 4 week 6) is shown in (Table 3). Particle size of the different diets particle size (Table 4). However, relative weight of heart was significantly higher for broilers fed RBD compared to broilers fed GBD. The mechanism behind the influence of regarding coarse

Table (3): Influence of barley particle size on broiler performance during 4 to 6 week old.

\begin{tabular}{|c|c|c|c|}
\hline & \multicolumn{2}{|c|}{ Particle size } & \multirow[b]{2}{*}{ P value } \\
\hline & GBD* & RBD** & \\
\hline Initial body weight (g) & $712.3 \pm 22.36$ & $667.7 \pm 19.43$ & 0.17 \\
\hline Final body weight (g) & $2476.5 \pm 49.63$ & $2323.5 \pm 86.41$ & 0.16 \\
\hline \multicolumn{4}{|l|}{ Week 4} \\
\hline ADG (g/day) & $67.83 \pm 3.8$ & $59.31 \pm 2.4$ & 0.10 \\
\hline FCR (g/g) & $1.82 \pm 0.1$ & $1.94 \pm 0.08$ & 0.37 \\
\hline CFI (g) & $842.77 \pm 9.83$ & $797.95 \pm 33.89$ & 0.26 \\
\hline \multicolumn{4}{|l|}{ Week 5} \\
\hline ADG (g/day) & $70.37 \pm 4.53$ & $65.57 \pm 4.76$ & 0.48 \\
\hline FCR $(g / g)$ & $2.26 \pm 0.13$ & $2.27 \pm 0.12$ & 0.92 \\
\hline CFI (g) & $1114.9 \pm 21.65$ & $1027.4 \pm 37.99$ & 0.08 \\
\hline \multicolumn{4}{|l|}{ Week 6} \\
\hline ADG (g/day) & $88.5 \pm 5.12$ & $69.57 \pm 5.86$ & 0.48 \\
\hline FCR $(g / g)$ & $2.47 \pm 0.11$ & $2.14 \pm 0.16$ & 0.10 \\
\hline CFI (g) & $1499.1 \pm 25.18$ & $1370 \pm 38.03$ & 0.02 \\
\hline \multicolumn{4}{|l|}{$\frac{\text { Whole period }}{\text { (Week 4-week } 6 \text { old) }}$} \\
\hline ADG (g/day) & $81.1 \pm 4.17$ & $78.69 \pm 5.12$ & 0.51 \\
\hline FCR $(\mathrm{g} / \mathrm{g})$ & $1.95 \pm 0.08$ & $1.85 \pm 0.10$ & 0.09 \\
\hline CFI (g) & $3456.8 \pm 39.05$ & $3195.3 \pm 88$ & $\mathbf{0 . 0 3}$ \\
\hline
\end{tabular}

*Ground barley diet

** reground coarse-fraction barley diet

Table (4): Influence of barley particle size on broiler dressing percentage and relative organ weight (as a percentage of live weight $( \pm S E)$ ).

\begin{tabular}{|c|c|c|c|}
\hline \multirow[b]{2}{*}{ Item } & \multicolumn{2}{|c|}{ Particle size } & \multirow[b]{2}{*}{ P value } \\
\hline & GBD* & RBD** & \\
\hline Dressing \% & $72.73 \pm 1.41$ & $73.66 \pm 2.07$ & 0.66 \\
\hline Gizzard relative weight $(\mathrm{g} / \mathrm{g})$ & $1.70 \pm 0.07$ & $1.56 \pm 0.08$ & 0.21 \\
\hline Abdominal fat relative weight (g/g) & $0.37 \pm 0.05$ & $0.48 \pm 0.07$ & $\mathbf{0 . 2 3}$ \\
\hline Heart relative weight $(\mathrm{g} / \mathrm{g})$ & $0.45 \pm 0.01$ & $0.52 \pm 0.02$ & 0.04 \\
\hline Spleen relative weight $(\mathrm{g} / \mathrm{g})$ & $0.11 \pm 0.006$ & $0.14 \pm 0.02$ & 0.14 \\
\hline
\end{tabular}

*Ground barley diet

** reground coarse-fraction barley diet

barley did not significantly affect broiler's average daily gain (ADG), feed conversion ratio (FCR) and cumulative feed intake (CFI) during week 4 and week 5 although there was a tendency for lower CFI for broiler's fed RBD at the end of week $5(\mathrm{P}=0.08)$. By the end of week 6, CFI was lower in broiler's fed RBD (1027.4 $\mathrm{gm})$ compared to broilers fed GBD (1114.9 gm). Generaly, bird group fed RBD recorded better values of FCR and lower values for CFI throughout the experimental period (4-6 week old) compared to group fed GBD.

Dressing percentage, gizzard (as a percent of live weight), abdominal fat weights and spleen relative weight $(\mathrm{g} / \mathrm{g})$ were not affected by particles on the relative relative weight of heart is unclear. It has been reported that different grain particles sizes have different kinetics of starch digestion; smaller particles have a higher starch digestion rate (Al-Rabadi et al. 2009). Synchronous absorption of glucose and amino acids by poultry can increase metabolizable energy delivery and may reduce amino acid oxidation and thus enhance protein retention (van den Borne et al., 2007). Consequently, the possible synchronous in amino acid and glucose absorption may increased heart relative weight in broilers fed RBD. 
Results in (Table 5) showed insignificant differences in gizzard $\mathrm{pH}$ and proventriculus $\mathrm{pH}$ between the two bird group feds RBD and GBD. particle size when broiler feed wheat-corn (Nir et al., 1994) or sorghum (Nir et al., 1990) based diets. The reduction in feed intake between the two groups may be attributed to that the

Table (5): Gizzard and proventriculus $\mathrm{pH}( \pm \mathrm{SD})$ in broiler chickens at 42 days of age fed diets with different particle sizes.

\begin{tabular}{|l|c|c|c|}
\hline & \multicolumn{2}{|c|}{ Particle size } & \\
\hline Item & GBD & RBD & P value \\
\hline Gizzard pH & $4.09 \pm 0.08$ & $4.23 \pm 0.06$ & 0.24 \\
\hline Proventriculus pH & $5.08 \pm 0.09$ & $4.98 \pm 0.06$ & 0.40 \\
\hline
\end{tabular}

The influence of barley particle size on conformational characteristics (length of digestive system organs) of broiler digestive system is shown in Table (6). The obtained results revealed that conformational characteristics were significantly affected by particle size of barley grain fragment in the diets. In all measured digestive components (small intestine, large intestine, and ceca), the length was significantly lower for broilers fed RBD compared to broilers fed GBD. digestive system of poultry fed RBD became impacted as a result of viscous digesta from finely ground barley. Barley is well known to have beta-glucan which is responsible for increasing digesta viscosity (Smith et al., 2008, Fincher, 1975). High viscosity profiles have been reported to characterize fine barley fractions compared to coarse fractions (AlRabadi 2013). Viscosity caused by beta glucan in barley has been reported to decrease endogenous enzyme activity and to induce

Table (6): Length of digestive system parts $( \pm \mathrm{SE})$ of 42 day-old broilers fed diet with different particle size.

\begin{tabular}{|l|c|c|c|}
\hline & \multicolumn{2}{|c|}{ Particle size } & \\
\hline Item & GBD & RBD & P value \\
\hline Pancreas Length (cm) & $12.84 \pm 0.47$ & $\mathbf{1 1 . 6 7} \pm \mathbf{0 . 1 8}$ & $\mathbf{0 . 0 4}$ \\
\hline Small intestine length $(\mathbf{c m})$ & $\mathbf{1 7 9 . 4 9} \pm \mathbf{2 . 7 3}$ & $\mathbf{1 6 2 . 4 1} \pm \mathbf{1 . 9 8}$ & $\mathbf{0 . 0 0 1}$ \\
\hline duodenum length $(\mathrm{cm})$ & $\mathbf{2 9 . 2 4} \pm \mathbf{0 . 4 6}$ & $\mathbf{2 7 . 2 8} \pm \mathbf{0 . 5 2}$ & $\mathbf{0 . 0 2}$ \\
\hline Jejunum length $(\mathbf{c m})$ & $\mathbf{8 7 . 5 9} \pm \mathbf{1 . 6 6}$ & $\mathbf{8 0 . 1 7} \pm \mathbf{1 . 6 0}$ & $\mathbf{0 . 0 1}$ \\
\hline Ileum length $(\mathbf{c m})$ & $\mathbf{6 2 . 6 6} \pm \mathbf{2 . 3 1}$ & $\mathbf{5 4 . 9 7} \pm \mathbf{0 . 9 5}$ & $\mathbf{0 . 0 2}$ \\
\hline Large intestine $(\mathbf{c m})$ & $\mathbf{3 2 . 5 2} \pm \mathbf{0 . 6 4}$ & $\mathbf{2 9 . 4 3} \pm \mathbf{0 . 8 7}$ & $\mathbf{0 . 0 2}$ \\
\hline Ceca length $(\mathbf{c m})$ & $\mathbf{2 3 . 0 9} \pm \mathbf{0 . 8 4}$ & $\mathbf{2 0 . 6 7} \pm \mathbf{0 . 3 4}$ & $\mathbf{0 . 0 3}$ \\
\hline
\end{tabular}

\section{DISCUSSIONS}

The regrinding approach of coarse fractions of barley grains did not increase the amount of very fine particles which are associated with potential handling in feed mills, under development of gizzard and enlargement proventriculus (Taylor and Jones, 2004). There was only a modest increase in particles of $<0.5$ $\mathrm{mm}$ considered to be the cut-off for causing handling problems at feed mill and improper function in digestive system in poultry and thus over all bird performance (Amerah et al., 2007 a $\&$ b). Fine particles have been reported to cause a bridging problem in bins and feeder and increase dustiness of the feed (Goodband et al., 1995).

Reduction in feed intake has been previously reported to be associated with reduction in feed morphological changes in the digestive system (Jacob and Pescatore, 2012). Highly viscous digesta have been reported to decrease feed intake when poultry fed finely ground wheat (Amerah et al., 2007a). However, no influence of particle size has been reported to affect poultry feed efficiency (Amerah et al., 2007b).

Many researchers reported that feeding coarse feed particles can stimulate gastric secretion and reduce proventriculus and gizzard pH (Cumming, 1994; Gabreial et al., 2003). However, the differences in this study were not significant (Table 5).

Feed particle has been shown to affect the development of the digestive system segments in poultry fed mash diets (Nir et al., 1995; Gabriel et al., 2003). It could be notice that the digestive system of poultry fed RBD became more 
impacted as a result of viscous digesta when fed RBD. Recent study showed that fine fragments of barley have a higher viscosity compared to coarse particles (Al-Rabadi 2013). Previous research of Amerah et al. (2007a) showed that fine particles can cause viscous digesta and consequently shortened the length of the digestive system. In this study, the relative length of pancreas was higher in GBD compared to RBD. Coarse particles have been reported to increase cholecystokinin release (Svihus et al., 2004), which stimulates and enhanced the secretion of pancreatic enzymes (Duke, 1992; Li and Owyang, 1993).

In conclusion, the outcomes of this study suggest that regrinding coarse particles reduced the percentage of coarse fractions retained on sieves $2.8 \mathrm{~mm}$ and $2.0 \mathrm{~mm}$ without increasing the amount of very fine particles which have potential application in feed industry. Regrinding coarse particles of barley could be an approach to reduce the production cost of broiler feed through minimizing feed intake without producing excess of fines.

\section{Acknowledgment}

The authors would like to thank FEEDCO Company (Amman-Jordan) represented by Dr. Arwa Al-Rawashdeh and Deanship of Academic Research-Mutah University for funding this project. In addition, the authors would like to thank Mrs Safa Abu Samhadaneh for her assistace.

\section{REFERENCES}

Al-Rabadi G. J. (2013). Effect of hammer mill screen size on processing parameters and starch enrichment in milled barley. Jordan J. Agric. Sci. 9: 162-169.

Al-Rabadi G. J., Gilbert R. and Gidley M. (2009). Effect of particle size on kinetics of starch digestion in milled barley and sorghum grains by porcine alpha-amylase. J. Cereal Sci. 50 (2): 198-204.

Amerah A. M., Ravindran V., Lentle R.G. and Thomas D.G. (2007a). Performance and digestive tract characteristics of broilers as influenced by particle size and feed form. Proceedings of the Australian Poultry Science Symposium 19: 85-88.

Amerah A. M., Ravindran V., Lentle R.G. and Thomas D.G. (2007b). Feed particle size: Implications on the digestion and performance of poultry. World Poultry Sci. J. 63: 439-455.
ASAE (2003). Method of Determining and Expressing Fineness of Feed Materials by Sieving. Standard no. S319.3. American Society of Agricultural and Biological Engineers, 602-605.

Blasel H. M., Hoffman P.C. and Shaver R. D. (2006). Degree of starch access: An enzymatic method to determine starch degradation potential of corn grain and corn silage. Anim. Feed Sci. and Tech. 128: 96-107.

Cumming R. B. (1994). Opportunities for whole grain feeding. Proceedings of the 9th European Poultry Conference, Vol. 2, pp. 219-222, World Poult. Sci. Assoc. Glasgow, United Kingdom.

Duke G. E. (1992). Recent studies on regulation of gastric motility in turkeys. Poult. Sci. 81: $1-8$.

Fincher G. B. (1975). Morphology and chemical composition of barley endosperm cellwalls. J. Inst. Brew. 81:116-122.

Gabriel I., Mallet S. and Leconte M. (2003). Differences in the digestive tract characteristics of broiler chickens fed on complete pelleted diet or on whole wheat added to pelleted protein concentrate. British Poult Sci. 44: 283-290.

Goodband R. D., Tokach M. D. and Nelssen J. L. (1995). The effects of diet particle size on animal performance. MF-2050. Feed Manufacturing, Manhattan, KS.,USA.

Gomez K.A. and Gomez A.A. (1984). statistical procedures for Agricultural Research $2^{\text {nd }}$ Ed. John wiley, New yourk, USA.

Healy B. J., Hancock J. D., Kennedy G. A., Bramelcox P. J., Behnke K. C. and Hines R.H. 1994. Optimum particle-size of corn and hard and soft sorghum for nursery pigs. J. of Anim. Sci. 72:2227-2236.

Jacob J.P. and Pescatore A. J. (2012). Use of barley in poultry diets: A review. J. Appl. Poult. Res. 21: 915-940.

Koch K. (1996). Hammer mills and roller mills. MF-2048 Feed Manufacturing, Department of Grain Science and Industry, Kansas State University. U S A, pp 8.

Li Y. and Owyang C. (1993). Vagal afferent pathway mediates physiological action of Cholecystokinin on pancreatic enzyme secretion. J. Clin. Invest. 92: 418-424.

Nir I., Hillel R., Ptichi I. and Shefet G. (1995). Effect of particle size on performance.3. 
Grinding pelleting interactions. Poult. Sci. 74: 771-783.

Nir I., Melcion J. P and Picard M. (1990). Effect of particle size of sorghum grains on feed intake and performance of young broilers. Poult. Sci. 69: 2177-2184.

Nir I., Shefet G. and Aaroni Y. (1994). Effect of particle size on performance. 1. Corn. Poult. Sci. 73: 45-49.

NRC (1994). Nutrient requirements of poultry. Ninth Revised Edition, National Academ Press, Washington D.C.

Smith K. N., Queenan K. M., Thomas W., Fulcher R. G. and Slavin J. S. (2008). Physiological effects of concentrated barley $\quad \beta$-glucan in mildly hypercholesterolemic adults. J. Amer. College Nutr. 27: 434-440.
Svihus B., Klovstad K.H., Perez V., Zimonja O., Sahlstrom S. and Schuller R.B. (2004). Physical and nutritional effects of pelleting of broiler chicken diets made from wheat ground to different coarsenesses by the use of roller mill and hammer mill. Anim. Feed Sci. and Tech. 117: 281-293.

Taylor R.D. and Jones G.P.D. (2004). The incorporation of whole grain into pelleted broiler chicken diet. 2. Gastrointestinal and digesta characteristics. British Poult Sci. 45: 237-246.

van den Borne, J.J.G.C., Schrama, J.W., Heetkamp, M.J.W., Verstegen, M.W.A., and Gerrits W.J.J., (2007). Synchronising the availability of amino acids and glucose increases protein retention in pigs. Animal 1: 666-674.

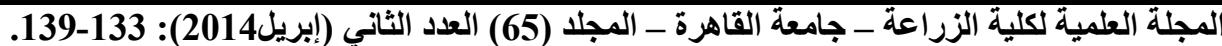

